\title{
Kepemimpinan dan Kinerja Karyawan di Lingkungan PT. Antavaya Travel Area Bandung
}

\author{
Teddy Luthfi, DJ Suyaman, Sonny Hersona \\ Universitas Singaperbangsa Karawang \\ satriashakti2016@gmail.com \\ jajang@fe.unsika.ac.id \\ Sonny@fe.unsika.ac.id
}

\begin{abstract}
ABSTRAK
Setiap organisasi atau instansi baik formal maupun informal dalam melaksanakan program yang diarahkan selalu berdaya guna untuk mencapai tujuan instansi. Salah satu caranya adalah dengan meningkatkan kinerja pegawai. Pegawai merupakan Sumber Daya Manusia (SDM) yang sangat penting dalam menentukan kemajuan dan terciptanya tujuan yang telah ditentukan. Dalam meningkatkan kinerja karyawan dibutuhkan faktor-faktor yang mendukung diantaranya yaitu Kepemimpinan. Kajian yang dilakukan peneliti pada saat ini mengarah pada peningkatan kinerja karyawan di PT. Antavaya Corporate travel. Dimana PT. Antavaya Corporate Travel Merupakan perusahaan manajemen perjalanan terkemuka di Indonesia, Membantu perusahaan dari semua ukuran, multinasional dan lembaga pemerintah mengelola perjalanan secara profesional dan hemat biaya. Antavaya Corporate Travel adalah perusahaan Travel Management terbesar di Indonesia. Yang didirikan pada tahun 1965, telah mendapatkan reputasi kualitas layanan dan manajemen profesional yang tiada duanya. Inti permasalahan dalam penelitian ini belum optimalnya kinerja pegawai, dan bertujuan untuk 1) Mengetahui bagaimana kepemimpinan di PT. Antavaya corporate travel 2) Mengetahui seberapa besar pengaruh kepemimpinan terhadap kinerja karyawan di PT.Antavaya corporate travel. Hasil penelitian menunjukkan bahwa ada pengaruh yang signifikan antara Kepemimpinan terhadap kinerja karyawan.
\end{abstract}

Kata Kunci : Kepemimpinan, Kinerja Pegawai

\begin{abstract}
Every organization or agency, both formal and informal, in carrying out programs that are directed to always be efficient to achieve agency goals. One way is to improve employee performance. Employees are Human Resources (HR) who are very important in determining progress and the creation of predetermined goals. In improving employee performance, supporting factors are needed including leadership. The study conducted by researchers at this time leads to an increase in employee performance at PT. Antavaya Corporate travel. Where is PT. Antavaya Corporate Travel is Indonesia's leading travel management company, helping companies of all sizes, multinationals and government agencies manage travel professionally and cost-effectively. Antavaya Corporate Travel is the largest Travel Management company in Indonesia. Founded in 1965, it has earned a reputation for quality service and professional management that is second to none. The core of the problem in this study is not yet optimal employee performance, and aims to 1) Knowing how leadership at PT. Antavaya corporate travel 2) Knowing how much influence leadership has on employee performance at PT. Antavaya corporate travel. The results showed that there was a significant influence between leadership on employee performance.
\end{abstract}

Keywords: Leadership, Employee Performance

\section{PENDAHULUAN}

Dalam suatu organisasi, Sumber Daya Manusia (SDM) sangatlah penting. Karena SDM mempunyai peran sebagai pengelola agar sistem tetap berjalan sesuai aturan.Dalam hal ini manajemen menjadikan SDM sebagai salah satu indikator penting dalam pencapaian tujuan organisasi.

Sumber Daya Manusia merupakan aset organisasi yang sangat vital. Peran dan fungsinya tidak dapat digantikan oleh sumber daya lainnya. SDM dianggap penting karena dapat mempengaruhi efisiensi dan efektivitas organisasi. Manusia selalu berperan aktif bukan hanya sebagai alat dalam produksi tetapi juga berperan aktif dalam kegiatan produksi.SDM juga merupakan penggerak dan penentu berlangsungnya proses produksi serta segala aktivitas organisasi. SDM memiliki andil besar dalam menentukan maju mundurnya suatu organisasi . Oleh karena itu, kemajuan suatu organisasi ditentukan pula oleh kualitas dan kapabilitas SDM di dalamnya. Di sinilah 
pentingnya manajemen SDM demi pengembangan organisasi. Dengan begitu, manusia sebagai aset organisasi harus dijaga serta ditingkatkan efisiensi dan produktivitasnya dalam bekerja.

Dalam pelaksanaan pekerjaannya, seorang karyawan atau pegawai menghasilkan sesuatu yang disebut dengan kinerja. Kinerja merupakan hasil kerja secara kualitas dan kuantitas yang dicapai oleh seorang pegawai dalam melaksanakan tugasnya sesuai dengan tanggung jawab yang diberikan kepadanya (Mangkunegara, 2016: 67). Bila kinerja pegawai baik, maka kinerja organisasi pun akan baik.

Dalam meningkatkan kinerja karyawan dibutuhkan faktor-faktor yang mendukung diantaranya yaitu Kepemimpinan. Seorang pemimpin pada dasarnya mempunyai pengaruh dan peran untuk menuju terwujudnya suatu tujuan organisasi atau perusahaan. Keselarasan hubungan antara pemimpin dan karyawan perlu diupayakan karena kondisi ini akan membantu terlaksananya pekerjaan sesuai dengan ketentuan. Sebagaimana diketahui bahwa seorang pemimpin mempunyai berbagai macam gaya dan sifat dalam memimpin karyawannya.

Kepemimpinan menurut Rivai (2014 :3) adalah, "Suatu perilaku dengan tujuan tertentu untuk mempengaruhi aktivitas para anggota kelompok untuk mencapai tujuan bersama yang dirancang untuk memberikan manfaat individu dan organisasi. Kepemimpinan menurut Danim (2012:56) yaitu, Setiap perbuatan yang dilakukan oleh individu atau kelompok untuk mengkoordinasi dan memberi arah kepada individu atau kelompok di dalam wadah tertentu untuk mencapai tujuan yang telah ditetapkan sebelumnya. Sedangkan kepemimpinan menurut Handoko (1997: 294-295) adalah "Kepemimpinan yang dipunyai seseorang untuk mempengaruhi orang lain agar bekerja untuk mencapai tujuan dan sasaran.”

Kepemimpinan adalah cara seorang pemimpin mempengaruhi perilaku bawahan agar mau bekerjasama dan bekerja secara produktif untuk mencapai tujuan organisasi (Hasibuan, 2011: 170). Menurut Badeni (2013: 2), kepemimpinan dapat didefinisikan sebagai kemampuan seseorang untuk mempengaruhi suatu kelompok ke arah tercapainya tujuan. Robbins dan Judge (2015: 410) menyatakan bahwa kepemimpinan adalah kemampuan mempengaruhi suatu kelompok menuju pencapaian sebuah visi atau serangkaian tujuan.

PT. Antavaya Tour Merupakan perusahaan manajemen perjalanan terkemuka di Indonesia, Membantu perusahaan dari semua ukuran , multinasional dan lembaga pemerintah mengelola perjalanan secara profesional dan hemat biaya.
Antavaya Corporate Travel adalah perusahaan Travel Management terbesar di Indonesia. Yang didirikan pada tahun 1965, telah mendapatkan reputasi kualitas layanan dan manajemen profesional yang tiada duanya. Berdasarkan observasi permasalahan yang ada pada PT.Antavaya Tour Area Bandung ini adalah belum optimalnya kinerja pegawai yang diakibatkan karena faktor kepemimpinan :

1) Kurangnya ketegasan seorang Manager area dalam memimpin dan kurangnya komunikasi yang baik

2) Pimpinan yang kurang menerapkan kedisiplinan pulang dan berangkat kerja tidak tepat waktu

3) Pimpinan yang kurang mampu mengawasi Karyawan untuk bekerja sesuai dengan yang telah ditentukan

4) Manajer Area kurang melakukan evaluasi serta kurang efektifnya Manajer dalam memonitor kerja karyawannya.

\section{KAJIAN PUSTAKA}

\section{Manajemen Sumber Daya Manusia}

Manajemen sumber daya manusia adalah suatu cara mencapai tujuan dengan cara menggerakkan organisasi yang dilakukan melalui perencanaan, pengorganisasian, pelaksanaan, dan pengendalian yang baik, sehingga menjadi sumber daya yang terdidik, terampil, cakap, berdisiplin, tekun, kreatif, idealis, mau bekerja keras, kuat fisik dan mental, serta setia kepada tujuan organisasi akan berpengaruh positif terhadap keberhasilan dan kemajuan organisasi. Menurut Simarmora dalam Sutrisno (2014: 5) menyatakan, manajemen sumber daya manusia adalah pendayagunaan, pengembangan, penilaian, pemberian balas jasa, dan pengelolaan individu anggota organisasi atau kelompok pekerja. Menurut Hasibuan (2014: 10) manajemen sumber daya manusia adalah ilmu dan seni mengatur hubungan dan peranan tenaga kerja agar efektif dan efisien membantu terwujudnya tujuan perusahaan, karyawan dan masyarakat.

Fungsi manajemen sumber daya manusia sangat penting dalam pencapaian tujuan perusahaan baik dalam jangka pendek maupun jangka panjang. Secara garis besar fungsi sumber daya manusia seperti yang dikemukakan Hasibuan (2014:22) terbagi dua fungsi yaitu manajerial, dan fungsi operasional sebagai berikut:

1) Fungsi-fungsi Manajerial meliputi:
a. Perencanaan (planning)
b. Pengorganisasian (organizing)
c. Pengarahan (directing)
d. Pengendalian (controlling) 
2) Fungsi-fungsi operasional
a. Pengadaan (procurement)
b. Pengembangan (development)
c. Kompensasi (compensation)
d. Pengintegrasian (integration)
e. Pemeliharaan (maintenance)
f. Kedisiplinan
g. Pemberhentian

Sidik Priadana (2017: 10) mengungkapkan bahwa, manajemen sumber daya manusia adalah manajemen yang memfokuskan diri memaksimalkan kemampuan karyawan atau anggotanya melalui berbagai langkah strategis dalam rangka meningkatkan kinerja pegawai/karyawan menuju pengoptimalan tujuan organisasi secara efektif dan efisien sesuai dengan tujuan strategis organisasi, dengan fungsi-fungsi diantaranya adalah:

1) Data Kepegawaian;

2) Perencanaan dan Pengembangan;

3) Rekrutmen;

4) Kompensasi dan Kesejahteraan;

5) Penilaian dan penghargaan;

6) Memotivasi;

7) Pemeliharaan;

8) Pengintegrasian;

9) Kesehatan kerja.

Sedarmayanti (2014: 13-14) menyatakan bahwa tujuan manajemen sumber daya manusia secara umum adalah untuk memastikan bahwa organisasi mampu mencapai keberhasilan melalui orang. Manajemen sumber daya manusia adalah kebijakan dan praktik menentukan aspek manusia atau sumber daya manusia dalam posisi manajemen, termasuk merekrut, menyaring, melatih, memberi penghargaan dan penilaian.

\section{Kepemimpinan}

Kreitner dan Kinicki (2010:467) mendefinisikan kepemimpinan sebagai proses dimana seorang individu mempengaruhi orang lain untuk mencapai tujuan bersama. McShane dan Von Glinow (2010: 360) menyatakan kepemimpinan adalah tentang memengaruhi, memotivasi, dan memungkinkan orang lain memberikan kontribusi ke arah efektivitas dan keberhasilan organisasi di mana mereka menjadi anggotanya. Kepemimpinan adalah proses mempengaruhi dan mendukung orang lain untuk bekerja secara antusias menuju pada pencapaian sasaran (Newstrom, 2011:171). Kepemimpinan merupakan faktor penting yang membantu individu atau kelompok mengidentifikasi tujuannya, dan kemudian memotivasi dari dalam mencapai tujuan yang telah ditetapkan.
Menurut Tjiptono (2011: 67) gaya kepemimpinan adalah suatu cara yang digunakan pemimpin dalam berinteraksi dengan bawahannya. Sementara itu, pendapat lain menyebutkan bahwa gaya kepemimpinan adalah pola tingkah laku (kata-kata dan tindakantindakan) dari seorang pemimpin yang dirasakan oleh orang lain (Hersey, 2004).

Pendapat yang serupa dikemukakan oleh Nawawi (2003: 21) gaya kepemimpinan adalah perilaku atau cara yang dipilih dan dipergunakan pemimpin dalam mempengaruhi pikiran, perasaan, sikap dan perilaku para anggota organisasi bawahannya.

Indikator indikator pemimpin yang didambakan menurut Ki Hajar Dewantara dalam Rivai, dkk( 2014:26-27), adalah sebagai berikut :

1) Ing Ngarso Sung Tulodo

Artinya di depan memberi contoh dan teladan . Pemimpin harus berani tampil di depan dengan senantiasa memberi contoh dan keteladanan.

\section{2) Ing Madyo Mangun Karso}

Artinya ditengah membengun karsa, gagasan, ide dan karya. Seorang pemimpin harus berada ditengah anggotanya dengan membangun karya, karsa dan gagasan.

\section{3) Tut Wuri Handayani}

Artinya di belakang memberikan dorongan atau motivasi. Seorang pemimpin jika dibelakang, selalu memberikan petunjuk, selalu mendorong dan memotivasi.

\section{Kinerja}

Kinerja merupakan hasil kerja secara kualitas dan kuantitas yang dicapai oleh seorang pegawai dalam melaksanakan tugasnya sesuai dengan tanggung jawab yang diberikan kepadanya (Mangkunegara, 2016: 67).

Mathis dan Jackson (2016: 378) menyatakan, kinerja merupakan sesuatu yang berhubungan dengan sistem rancangan formal dalam suatu organisasi untuk menentukan dan efisiensi dilihat dari bakat seseorang untuk mewujudkan sasaran suatu organisasi. Dari definisi tersebut ada beberapa indikator kinerja yaitu:

1) Kuantitas dari hasil;

Merupakan jumlah yang dihasilkan, dinyatakan dalam istilah seperti jumlah unit, jumlah siklus aktivitas yang diselesaikan karyawan, dan jumlah aktivitas yang dihasilkan.

2) Kualitas dari hasil;

Kualitas kerja diukur dari persepsi karyawan 
terhadap kualitas pekerjaan yang dihasilkan serta kesempurnaan tugas terhadap keterampilan dan kemampuan karyawan.

3) Ketepatan waktu (jangka waktu output);

Ketepatan waktu dari persepsi karyawan terhadap suatu aktivitas yang diselesaikan di awal waktu sampai menjadi output.

4) Kehadiran;

Kehadiran karyawan di perusahaan baik dalam masuk kerja, pulang kerja, izin, maupun tanpa keterangan yang seluruhnya mempengaruhi kinerja karyawan itu.

5) Kemampuan bekerjasama;

Kemampuan bekerja sama adalah kemampuan seseorang tenaga kera untuk bekerja sama dengan orang lain dalam menyelesaikan suatu tugas dan pekerjaan yang telah ditetapkan sehingga mencapai daya guna dan hasil yang yang sebesar-besarnya.

\section{Profil PT. Antavaya Corporate Travel Area Bandung}

PT.Antavaya Corporate Travel Merupakan perusahaan manajemen perjalanan terkemuka di Indonesia, Membantu perusahaan dari semua ukuran , multinasional dan lembaga pemerintah mengelola perjalanan secara profesional dan hemat biaya. Antavaya Corporate Travel adalah perusahaan Travel Management terbesar di Indonesia. Yang didirikan pada tahun 1965, telah mendapatkan reputasi kualitas layanan dan manajemen profesional yang tiada duanya.

PT. Antavaya Tour travel area Bandung Beralamatkan di Jalan Lengkong kecil No.28, Paledang, Kecamatan Lengkong, Kota Bandung Jawa Barat.

PT Antavaya Tour Travel memiliki visi, misi dan tujuan yaitu :

Visi :Menjadi agen perjalanan terbaik dan terbesar di Indonesia.

Misi :Menyediakan layanan berkualitas dan bernilai tambah dengan memberi

pengalaman bepergian yang memuaskan dan mengesankan bagi para pelanggan.

Tujuan (AntaVaya Way) :Bertujuan untuk menyenangkan pelanggan dengan memberikan layanan yang unggul sehingga mengemulasi setiap karyawan untuk menerapkan AntaVaya Way

Adapun karyawan PT. Antavaya Tour Travel Area Bandung terdiri dari 29 karyawan tetap yang dipimpin oleh seorang Area Manager yang membawahi dua divisi yaitu Tour Manager dan
Ticketing dan Umroh Manager. Berikut tabel karyawan berdasarkan jabatannya :

Tabel 1 Jabatan Karyawan

\begin{tabular}{clc}
\hline NO & \multicolumn{1}{c}{ JABATAN } & $\begin{array}{c}\text { JUMLAH } \\
\text { KARYAWAN }\end{array}$ \\
\hline 1 & AREA MANAGER & 1 \\
\hline 2 & TOUR MANAGER & 1 \\
\hline 3 & TICKETING \& UMROH MANAGER & 1 \\
\hline 4 & FINANCE ACCOUNTING & 3 \\
\hline 5 & OPERATION CORP & 4 \\
\hline 6 & SALES & 1 \\
\hline 7 & MICE & 1 \\
\hline 8 & OPERATION & 2 \\
\hline 9 & TSM SUPERVISOR & 5 \\
\hline 10 & LENGKONG SUPERVISOR & 4 \\
\hline 11 & PASCAL SUPERVISOR & 4 \\
\hline 12 & UMROH & 2 \\
\hline & $\quad$ JUMLAH & $\mathbf{2 9}$ \\
\hline
\end{tabular}

\section{METODE PENELITIAN}

Metode yang digunakan penelitian adalah metode penelitian survei. Indrawan (dalam Dea, 2020: 71) menjelaskan bahwa metode survei adalah metode penelitian kuantitatif yang bertujuan untuk melihat keadaan yang menjadi objek penelitian apa adanya dengan melihat data dan informasi yang ada dari sampel tanpa perlakuan khusus. Teknik ini lazim menggunakan pengumpulan data dengan cara pengamatan langsung terhadap suatu gejala, wawancara, kuesioner terkirim, atau melalui telepon.

Sedangkan desain penelitian menggunakan model desain pendekatan hubungan kausal. Model desain ini digunakan untuk mengetahui hubungan antara dua variabel atau lebih di mana hubungan tersebut bersifat sebab-akibat (Sugiyono, 2018: 93).

Penentuan sampel dalam penelitian ini menggunakan pendekatan saturation sampling. Teknik ini merupakan teknik penentuan sampel di mana semua anggota populasi digunakan sebagai sampel. Oleh karena itu jumlah sampel yang akan diteliti yaitu sebanyak 29 orang yang terdiri dari pegawai PT Antavaya Tour Travel Area Bandung.

Data penelitian berasa dari data primer; yaitu data yang langsung didapatkan dari pihak pertama. Teknik pengumpulan data menggunakan kuesioner yang dibagikan kepada responden. Kuesioner tersebut menggunakan jawaban dengan skala Likert. 


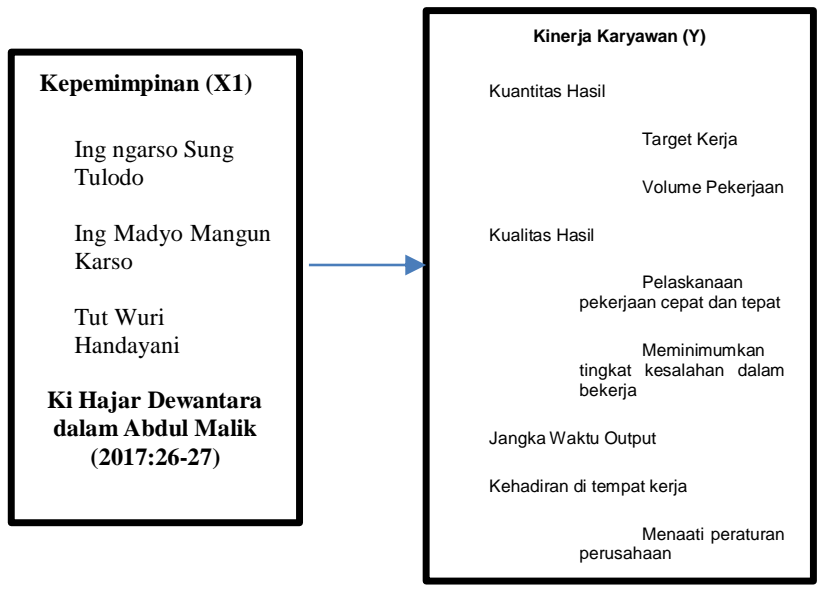

Gambar 1

Kerangka Pemikiran

Data kuesioner yang terkumpul kemudian dianalisis dengan teknik analisis regresi sederhana untuk menguji ada atau tidaknya pengaruh dan seberapa besar pengaruh Kepemimpinan terhadap Kinerja Karyawan..

\section{HASIL DAN PEMBAHASAN}

\section{Uji Validitas}

Untuk menguji validitas, peneliti menggunakan analisis dengan SPSS versi 23. Untuk tingkat validitas dilakukan uji signifikansi dengan membandingkan nilai $r_{\text {hitung }}$ dengan nilai $r_{\text {tabel }}$. Pada penelitian ini besarnya $r_{\text {tabel }}$ yaitu sebesar 0,3009. Jika $r_{\text {hitung }} \geq r_{\text {tabel }}$ dan nilai $r$ positif, maka butir pernyataan tersebut dikatakan valid. Rekapitulasi seluruh hasil uji validitas variabel Motivasi (X) dapat dilihat pada tabel berikut :

Tabel 2

Hasil Uji Validitas Variabel X Kepemimpinan

\begin{tabular}{cccc}
\hline No & $\mathbf{R}_{\text {hitung }}$ & $\mathbf{R}_{\text {tabel }}$ & Keterangan \\
\hline 1 & 0,7003 & 0.3009 & Valid \\
\hline 2 & 0,342 & 0.3009 & Valid \\
\hline 3 & 0,4778 & 0.3009 & Valid \\
\hline 4 & 0,4307 & 0.3009 & Valid \\
\hline 5 & 0,5242 & 0.3009 & Valid \\
\hline 6 & 0,6042 & 0.3009 & Valid \\
\hline 7 & 0,3084 & 0.3009 & Valid \\
\hline 8 & 0,5856 & 0.3009 & Valid \\
\hline 9 & 0,4964 & 0.3009 & Valid \\
\hline 10 & 0,3049 & 0.3009 & Valid \\
\hline 11 & 0,5157 & 0.3009 & Valid
\end{tabular}

(Sumber: Data Output SPSS 23 yang telah diolah, 2021)

Dapat dilihat dari tabel 2 diatas bahwa nilai $r_{\text {hitung }}$ dari pernyataan variabel kepemimpinan (X) lebih besar dari $r_{\text {tabel }}$ yaitu 0,3009, sehingga semua item pernyataan tersebut dinyatakan valid dan dapat digunakan dalam analisis data selanjutnya.
Setelah melakukan uji validitas pada variabel kepemimpinan (X), kemudian peneliti melakukan pengujian pada variabel Kinerja (Y). Rekapitulasi seluruh hasil uji validitas variabel Kinerja (Y) disajikan dalam tabel berikut ini :

Tabel 3

Hasil Uji Validitas Variabel Y Kinerja

\begin{tabular}{cccc}
\hline No & $\mathbf{R}_{\text {hitung }}$ & $\mathbf{R}_{\text {tabel }}$ & Keterangan \\
\hline 1 & 0,7003 & 0.3009 & Valid \\
\hline 2 & 0,342 & 0.3009 & Valid \\
\hline 3 & 0,4778 & 0.3009 & Valid \\
\hline 4 & 0,4307 & 0.3009 & Valid \\
\hline 5 & 0,5242 & 0.3009 & Valid \\
\hline 6 & 0,6042 & 0.3009 & Valid \\
\hline 7 & 0,3084 & 0.3009 & Valid \\
\hline 8 & 0,5856 & 0.3009 & Valid \\
\hline 9 & 0,4964 & 0.3009 & Valid \\
\hline 10 & 0,3049 & 0.3009 & Valid \\
\hline 11 & 0,5157 & 0.3009 & Valid
\end{tabular}

(Sumber : Data Output SPSS 23 yang telah diolah, 2021)

Berdasarkan tabel 3 diatas, terlihat bahwa setiap item pernyataan variabel Kinerja (Y) dalam kuesioner penelitian ini dinyatakan valid. Dapat dikatakan valid karena nilai $r_{\text {hitung }}$ lebih besar dibandingkan dengan nilai $r_{\text {tabel }}$ yaitu 0,3009 dan dapat digunakan dalam analisis data selanjutnya.

\section{Uji Reliabilitas}

Uji reliabilitas dilakukan dengan menghitung nilai cronbach's alpha dalam masing-masing instrumen dalam suatu variabel. Nilai untuk menentukan reliabilitas suatu instrumen adalah nilai cronbach's alpha lebih besar dari nilai $r_{\text {tabel }}$ sebesar 0,60. Perhitungan uji reliabilitas instrumen dalam penelitian ini menggunakan SPSS versi 23, hasil dari pengolahan data yang dilakukan oleh peneliti dalam penelitian ini akan disajikan dalam tabel berikut ini :

Tabel .4

Hasil Uji Reliabilitas Variabel X Kepemimpinan

Reliability Statistics

\begin{tabular}{rr}
\hline $\begin{array}{c}\text { Cronbach's } \\
\text { Alpha }\end{array}$ & N of Items \\
\hline 670 & 11
\end{tabular}

(Sumber : Data Output SPSS 23 yang telah diolah, 2021)

Berdasarkan tabel 4 diatas, pengujian yang dilakukan untuk mengetahui nilai cronbach's alpha untuk variabel kepemimpinan (X) sebesar 0,670. 
Nilai 0,670 lebih besar dari nilai $r_{\text {tabel }}$ yang ditentukan yaitu sebesar 0,60. Maka variabel independen kepemimpinan (X) dinyatakan reliabel sehingga dapat digunakan berulang-ulang.

Setelah melakukan uji reliabilitas pada variabel Kepemimpinan (X) peneliti melakukan pengujian pada variabel Kinerja (Y). Hasil uji reliabilitas variabel Kinerja (Y) disajikan dalam tabel berikut ini :

Tabel 5

Hasil Uji Reliabilitas Variabel Y Kinerja

\section{Reliability Statistics}

\begin{tabular}{rr}
\hline $\begin{array}{c}\text { Cronbach's } \\
\text { Alpha }\end{array}$ & N of Items \\
\hline .670 & 11 \\
\hline
\end{tabular}

(Sumber : Data Output SPSS 23 yang telah diolah, 2021)

Berdasarkan tabel 5 diatas, setiap item pernyataan variabel Kinerja (Y) atas pengujian yang dilakukan untuk mengetahui nilai cronbach's alpha untuk variabel Kinerja (Y) sebesar 0,670 lebih besar dari nilai $r_{\text {tabel }}$ yang ditentukan yaitu sebesar 0,60. Maka variabel Kinerja (Y) dinyatakan reliabel sehingga dapat digunakan berulang-ulang.

\section{Uji Normalitas}

Uji normalitas bertujuan untuk mengetahui apakah distribusi sebuah data mengikuti atau mendekati distribusi normal. Cara uji normalitas adalah dengan menggunakan uji statistik (uji Kolmogorov Smirnov). Uji Kolmogorov Smirnov memiliki kriteria jika nilai probabilitas $>0,05$, maka data berdistribusi normal, dan jika probabilitas < 0,05, maka data tidak berdistribusi normal. Berikut merupakan hasil uji Kolmogorov Smirnov :

\section{Tabel 6}

One-Sample Kolmogorov-Smirnov Test

\begin{tabular}{llr}
\hline & & $\begin{array}{c}\text { Unstandardize } \\
\text { d Residual }\end{array}$ \\
\hline $\mathrm{N}$ & $\begin{array}{r}29 \\
\text { Normal Parameters }\end{array}$ & .0000000 \\
& Std. Deviation & 2.77951069 \\
Most Extreme Differences & Absolute & .189 \\
& Positive & .100 \\
& Negative & -.189 \\
Test Statistic & & .189 \\
Asymp. Sig. (2-tailed) & & $.010^{c}$ \\
\hline
\end{tabular}

a. Test distribution is Normal.

b. Calculated from data.

c. Lilliefors Significance Correction.

(Sumber : Data Output SPSS 23 yang telah diolah, 2021)
Tabel 7

\section{Coefficients}

\begin{tabular}{|c|c|c|c|c|c|}
\hline \multirow[b]{2}{*}{ Model } & \multicolumn{2}{|c|}{$\begin{array}{l}\text { Unstandardized } \\
\text { Coefficients }\end{array}$} & \multirow{2}{*}{$\begin{array}{c}\begin{array}{c}\text { Standardize } \\
\mathrm{d} \\
\text { Coefficients }\end{array} \\
\text { Beta }\end{array}$} & \multirow[b]{2}{*}{$\mathrm{t}$} & \multirow[b]{2}{*}{ Sig. } \\
\hline & $\mathrm{B}$ & $\begin{array}{l}\text { Std. } \\
\text { Error }\end{array}$ & & & \\
\hline $\begin{array}{ll}1 & \text { (Constant) }\end{array}$ & 56.114 & 8.510 & & 6.594 & .000 \\
\hline Kepemimpinan & -.236 & .187 & -.236 & -1.260 & .219 \\
\hline
\end{tabular}

a. Dependent Variable: kinerja diolah,2021)

Berdasarkan tabel 7 diatas, menunjukkan hasil uji normalitas kedua variabel adalah sebesar 0,189 dengan asymp sig 0,10. Oleh karena itu nilai asym sig tersebut lebih besar dari 0,005 maka dapat disimpulkan bahwa data variabel Kepemimpinan (X) dan data variabel Kinerja (Y) dalam penelitian ini berdistribusi normal.

\section{Analisis Regresi Sederhana}

Analisis regresi sederhana adalah metode pendekatan untuk pemodelan hubungan antara satu variabel independen (X) dan satu variabel dependen (Y). Analisis ini digunakan untuk mengetahui arah hubungan antara variabel independen dengan variabel dependen apakah positif atau negatif dan untuk memprediksi nilai dari variabel dependen apabila nilai variabel independen mengalami kenaikan atau penurunan. Dalam penelitian ini model regresi yang digunakan adalah analisis regresi linier sederhana.

\section{Analisis Koefisien Korelasi}

Analisis koefisien korelasi adalah metode untuk mengetahui ada atau tidaknya hubungan linear antara variabel. Apabila terdapat hubungan, maka perubahan-perubahan yang terjadi pada salah satu variabel (X) akan mengakibatkan terjadinya perubahan pada variabel (Y) lainnya. Rumus koefisien korelasi yang digunakan adalah product moment yang merupakan statistik parametrik. Dengan kata lain tujuan analisis korelasi tersebut adalah untuk mengetahui apakah di antara dua variabel terdapat hubungan, dan jika terdapat hubungan adalah bagaimana arah hubungan dan seberapa besar hubungan tersebut.

Tabel 8

Hasil Analisis Koefisien Korelasi

Correlations

\begin{tabular}{llrr}
\hline \multirow{2}{*}{ Kepemimpinan } & \multicolumn{2}{r}{ kepemimpinan } & kinerja \\
\cline { 2 - 4 } & $\begin{array}{l}\text { Pearson } \\
\text { Correlation }\end{array}$ & 1 & -.236 \\
\cline { 2 - 4 } & Sig. (2-tailed) & 29 & .219 \\
\cline { 2 - 4 } & $\mathrm{N}$ & -.236 & 29 \\
\hline Kinerja & Pearson & .219 & 1 \\
& Correlation & 29 & 29 \\
\cline { 2 - 4 } & Sig. (2-tailed) & & \\
\cline { 2 - 4 } & $\mathrm{N}$ & & \\
& & & \\
\end{tabular}


Berdasarkan tabel 8 di atas, dapat diketahui bahwa koefisien korelasi yang diperoleh sebesar -0,236. Dengan demikian, besarnya hubungan antara pengaruh KEPEMIMPINAN (X) terhadap KINERJA (Y) sebesar 73,3\% dan ada pada interval 0,20 - 0,399 atau dapat dikatakan bahwa hubungan antara pengaruh Kepemimpinan (X) terhadap kinerja karyawan (Y) memiliki hubungan yang rendah (Sugiyono, 2017 : 184). Berikut merupakan tabel pedoman untuk memberikan interpretasi koefisien korelasi :

\section{4) Koefisien Determinasi}

Analisis koefisien determinasi digunakan untuk mengetahui seberapa besar pengaruh variabel $\mathrm{X}$ terhadap variabel Y. Nilai koefisien determinasi adalah nol atau satu. Nilai yang mendekati satu berarti variabel-variabel independen memberikan hampir semua informasi yang dibutuhkan untuk memprediksi variasi variabel-variabel dependen. Hasil penelitian dapat dilihat pada tabel dibawah ini

Tabel 9

\section{Hasil Analisis Koefisien Determinasi}

Model Summary ${ }^{\mathrm{b}}$

\begin{tabular}{|c|c|c|c|c|}
\hline Model & $\mathrm{R}$ & R Square & $\begin{array}{l}\text { Adjusted R } \\
\text { Square }\end{array}$ & $\begin{array}{l}\text { Std. Error of } \\
\text { the Estimate }\end{array}$ \\
\hline 1 & $.236^{\mathrm{a}}$ & .056 & .02 & 2.83052 \\
\hline
\end{tabular}

a. Predictors: (Constant), kepemimpinan

b. Dependent Variable: kinerja

Tabel 9 diatas menjelaskan besarnya nilai korelasi/hubungan (R) yaitu sebesar 0,236. Dari data tersebut diperoleh koefisien determinasi ( $\mathrm{R}$ Square) sebesar 0,236, yang mengandung pengertian bahwa pengaruh variabel bebas (Kepemimpinan) terhadap variabel terikat (kinerja) adalah sebesar $23,6 \%$.

\section{5) Uji Hipotesis}

Uji hipotesis ini dilakukan untuk mengetahui diterima atau ditolaknya hipotesis pada penelitian ini. Uji hipotesis ini dilakukan dengan melakukan uji signifikansi atau disebut juga dengan uji-t. Berikut adalah hasil uji hipotesis yang dihitung dengan menggunakan aplikasi SPSS versi 23 :

Tabel 10

Hasil Uji Hipotesis Secara Parsial (Uji t) Coefficients $^{\text {a }}$

\begin{tabular}{|c|c|c|c|c|c|c|}
\hline \multirow[b]{2}{*}{ Model } & & \multicolumn{2}{|c|}{$\begin{array}{l}\text { Unstandardized } \\
\text { Coefficients }\end{array}$} & \multirow{2}{*}{$\begin{array}{c}\text { Standardized } \\
\text { Coefficients } \\
\text { Beta }\end{array}$} & \multirow[b]{2}{*}{$\mathrm{T}$} & \multirow[b]{2}{*}{ Sig. } \\
\hline & & B & $\begin{array}{l}\text { Std. } \\
\text { Error }\end{array}$ & & & \\
\hline 1 & (Constant) & 56.114 & 8.510 & & 6.594 & .000 \\
\hline & $\begin{array}{l}\text { Kepemim- } \\
\text { pinan }\end{array}$ & -.236 & .187 & -.236 & $1.260^{-}$ & .219 \\
\hline
\end{tabular}

a. Dependent Variable: kinerja
Diketahui nilai constanta (a) sebesar 38,329, sedang nilai motivasi ( $\mathrm{b} /$ koefisien regresi ) sebesar 0,378 sehingga persamaan regresinya dapat ditulis :

$$
\begin{aligned}
& Y=a+b X \\
& Y=13,685+0,378 X
\end{aligned}
$$

Koefisien regresi $\mathrm{x}$ sebesar 0,378 menyatakan bahwa setiap penambahan $1 \%$ nilai kepemimpinan, maka nilai kinerja bertambah 0,378. Koefisien regresi tersebut bernilai positif, sehingga dapat dikatakan bahwa arah pengaruh variabel $\mathrm{x}$ terhadap y adalah positif. sehingga dapat disimpulkan bahwa $\mathrm{H}_{0}$ ditolak dan $\mathrm{H}_{\mathrm{a}}$ diterima. Hal ini menunjukkan bahwa ada pengaruh yang signifikan antara Kepemimpinan X) terhadap kinerja karyawan (Y).

\section{SIMPULAN DAN SARAN}

\section{Simpulan}

Adapun kesimpulan dari penelitian ini adalah Tingkat kinerja karyawan atau pegawai pada PT. Antavaya Travel Area pada posisi baik walaupun masih rendah.

Berdasarkan penelitian, Kepemimpinan sangat berpengaruh secara positif dan signifikan terhadap kinerja pegawai di lingkungan PT.Antavaya tour Area Bandung.

\section{Saran}

Adapun saran yang bisa peneliti berikan adalah tingkat kinerja karyawan atau pegawai diharapkan semakin ditingkatkan mengingat PT. Antavaya tour ini merupakan perusahaan Antavaya Travel Management terbesar di Indonesia. Yang didirikan pada tahun 1965, telah mendapatkan reputasi kualitas layanan dan manajemen profesional yang tiada duanya.

Setiap pegawai di lingkungan PT. Antavaya Tour diharapkan lebih bertanggungjawab dalam melaksanakan tugasnya, serta tetap terus meningkatkan prestasi kerja.

Sebagai seorang Pemimpin di Perusahaan yaitu Manajer Area PT. Antavaya tour diharapkan lebih meningkatkan Kedisiplinan, hubungan baik dengan para bawahannya dan bisa lebih tegas dalam memimpin dan mengambil keputusan karena Pimpinan merupakan panutan yang akan dicontoh segala perbuatannya oleh karyawan.

Sebagai seorang Pemimpin diharapkan untuk dapat meningkatkan pengawasan kepada para karyawan atau bawahannya untuk bekerja sesuai dengan yang telah ditentukan.

Sebagai seorang pemimpin dalam hal ini Manajer Area sebaiknya dapat melakukan evaluasi serta memonitor kerja karyawan agar efektif. 


\section{DAFTAR PUSTAKA}

\section{Buku}

Alma, Buchari. 2013. Manajemen Pemasaran dan Pemasaran Jasa. Bandung: Alfabeta.

Bangun Wilson.2013. Manajemen Sumber Daya Manusia. Jakarta: Erlangga.

Danim, Sudarwan. 2018. Motivasi Kepemimpinan dan Efektivitas Kelompok. Bandung: PT. Remaja Rosdakarya.

------------------. 2018. Perencanaan dan Pengembangan Sumber Daya Manusia. Bandung: Alfabeta.

Fahmi, Irham. 2016. Manajemen Sumber Daya Manusia Teori dan Aplikasi. Bandung: Alfabeta.

Handoko, Hani T. 2014. Manajemen Personalia dan Sumber Daya Manusia. Yogyakarta: BPFE.

Hasibuan, Malayu. 2014. Manajemen Sumber Daya Manusia. Jakarta: Bumi Aksara.

2015. Manajemen Sumber Daya Manusia. Jakarta: Bumi Aksara.

2017. Manajemen Sumber Daya Manusia. Jakarta: Bumi Aksara.

Indrawan Rully dan Poppy Yuniawati. 2014. Metodologi Penelitian, Kuantitatif, Kualitatif dan Campuran Untuk Manajemen, Pembangunan dan Pendidikan. Bandung: PT. Refika Aditama

Juni Priansa Doni. 2016. Perencanaan dan Pengembangan Sumber Daya Manusia. Bandung: CV. Alfabeta.

Juni Priansa Doni dan Garnida Agus. 2013. Manajemen Perkantoran Efektif, Efisien, dan Profesional. Bandung: CV. Alfabeta

Kusnendi. 2015. Analisis Jalur Konsep dan Aplikasi Program SPSS. Universitas Pendidikan Indonesia.

Manullang. 2018. Dasar-Dasar Manajemen. Jakarta: Ghalia Indonesia.

Marwansyah. 2014. Manajemen Sumber Daya Manusia Edisi Kedua. Bandung: Alfabeta.

Mathis, Jackson. 2016. Manajemen Sumber Daya Manusia. Edisi 9 dialihbahasakan oleh Jimmy Saedeli dan Bayu Prawira Hie, Jakarta: Salemba Empat.

Moeheriono. 2017. Pengukuran Kinerja Berbasis Kompetensi Edisi Revisi. Jakarta: PT. Raja Grafindo Persada.
Mondy, R. Wayne. 2008. Manajemen Sumber Daya Manusia. Jakarta: Erlangga

Muizu, Zustina Wa Ode. 2014. Pengaruh Kepemimpinan Terhadap Kinerja Karyawan. Vol 6 No.1 Hal. 1-13

Priadana Sidik. 2017. Metodologi Penelitian Ekonomi dan Bisnis. Yogyakarta: Graha Ilmu.

Robbins J. Stephen. 2016. Organizational Behaviour Edisi 13 Jilid 1. Jakarta: Salemba Empat.

2017. Organizational Behaviour, Edisi 14, Jilid 2, Salemba Empat, Jakarta.

Sarwono, Jonathan. 2017. Metode Riset Skripsi Pendekatan Kuantitatif Menggunakan Prosedur SPSS (Edisi Pertama). Jakarta: PT Elex Media Komputindo.

Sedarmayanti. 2014. Sumber Daya Manusia, Reformasi Birokrasi dan Manajemen Pegawai Negeri Sipil Bandung: Refika Aditama.

Sinambela, Lijan Poltak. 2012. Kinerja Pegawai (Teori Pengukuran dan Implikasinya). Yogyakarta: Graha Ilmu

Sikula F. Andrew. 2014. Manajemen Sumber Daya Manusia. Bandung: Erlangga.

Sugiyono. 2010. Metodologi Penelitian Pendidikan Kuantitatif, Kualitatif dan $R \& D$ Bandung: Alfabeta.

---------. 2014. Metodologi Penelitian Pendidikan Kuantitatif, Kualitatif dan $R \& D$ Bandung: Alfabeta.

-----------. 2018. Metodologi Penelitian Pendidikan Kuantitatif, Kualitatif dan $R \& D$ Bandung: Alfabeta.

Wibowo. 2014. Manajemen Kinerja Edisi Keempat. Jakarta: Rajawali Pers

Winardi. 2016. Manajemen Sumber Daya Manusia. Jakarta: PT Rineka Cipta. 